\title{
High prevalence of Helicobacter pylori infection in cohabiting children. Epidemiology of a cluster, with special emphasis on molecular typing
}

\author{
P Vincent, F Gottrand, P Pernes, M O Husson, M Lecomte-Houcke, D Turck, H Leclerc
}

\begin{abstract}
Intrafamilial cases of infection with the same strain of Helicobacter pylori (H pylori) have been reported but these clusters were too small to distinguish between person to person spread or coinfection from a common environmental source. To gain more information on the mode of transmission of $H$ pylori, an epidemiological survey with bacterial strain differentiation by restriction endonuclease analysis of chromosomal DNA was carried out in an institution of 117 children with encephalopathy (aged 3.5 to 19 years). All children with antibodies against $\boldsymbol{H}$ pylori had gastroscopy to obtain gastric biopsy specimens. The prevalence of infection (confirmed histologically or microbiologically, or both) was $38 \%$ (45/117), and rose to $67 \%$ in one of the five sections of the institution. $H$ pylori was isolated in 34/45 cases, and 22 different strains were found of which five strains were present in more than one child. Up to seven children were infected by the same strain, five of them were living in the same section. Analysis of the characteristics of infected children showed the predominant role of living conditions and the period of time cohabiting in this unexpectedly high prevalence of $\boldsymbol{H}$ pylori infection in children living in good sanitary conditions. (Gut 1994; 35: 313-316)
\end{abstract}

The source of infection as well as the mode of transmission of Helicobacter pylori ( $H$ pylori) are still unknown. The prevalence of infection increases with age and low standard of living. ${ }^{12}$ The high prevalence reported in institutionalised patients ${ }^{3-5}$ and in submarine crews ${ }^{6}$ suggests that people living in close contact have a high risk of infection. The same risk factors have been found for children as for adults, ${ }^{7-9}$ and a high prevalence has also been reported in an orphanage. ${ }^{10}$

TABLE I Characteristics of children and prevalence of $\mathrm{H}$ pylori infection, in the five sections of the institution

\begin{tabular}{|c|c|c|c|c|c|c|}
\hline & \multicolumn{5}{|l|}{ Section } & \multirow[b]{2}{*}{ p Value } \\
\hline & 1 & 2 & 3 & 4 & 5 & \\
\hline $\begin{array}{l}\text { No of children } \\
\text { Boys }(\%) \\
\text { Age } \\
\text { African }(\%) \\
\text { Mobile (\%) } \\
\text { Coordination (\%) } \\
\text { Dribbling (\%) } \\
\text { Anti-convulsant treatment (\%) }\end{array}$ & $\begin{array}{l}24 \\
37 \cdot 5 \\
12 \cdot 3(3 \cdot 9) \\
25 \cdot 0 \\
12 \cdot 5 \\
45 \cdot 8 \\
75 \cdot 0 \\
70 \cdot 8\end{array}$ & $\begin{array}{l}42 \\
58 \cdot 3 \\
12 \cdot 5(2 \cdot 9) \\
12 \cdot 5 \\
66 \cdot 7 \\
95 \cdot 8 \\
54 \cdot 2 \\
58 \cdot 3\end{array}$ & $\begin{array}{l}23 \\
69 \cdot 6 \\
10 \cdot 5(3 \cdot 2) \\
17 \cdot 4 \\
13 \cdot 0 \\
56 \cdot 5 \\
56 \cdot 5 \\
87 \cdot 0\end{array}$ & $\begin{array}{l}23 \\
52 \cdot 2 \\
9 \cdot 8(3 \cdot 3) \\
8 \cdot 7 \\
39 \cdot 1 \\
60 \cdot 9 \\
39 \cdot 1 \\
73 \cdot 9\end{array}$ & $\begin{array}{l}23 \\
52 \cdot 2 \\
10 \cdot 5(3 \cdot 2) \\
14 \cdot 6 \\
13 \cdot 0 \\
39 \cdot 1 \\
60 \cdot 9 \\
79 \cdot 3\end{array}$ & $\begin{array}{c}\text { NS } \\
<0.025 \\
\text { NS } \\
<0.001 \\
<0.001 \\
\text { NS } \\
\text { NS }\end{array}$ \\
\hline $\begin{array}{l}\text { Duration of stay }{ }^{\star} \text { in the } \\
\text { institution } \\
\text { Duration of stay }{ }^{\star} \text { in collectivity }\end{array}$ & $\begin{array}{l}6 \cdot 2(3 \cdot 4) \\
9 \cdot 2(5)\end{array}$ & $\begin{array}{l}4.9(2.6) \\
7.3(3.6)\end{array}$ & $\begin{array}{l}5.8(3.3) \\
7.9(3.4)\end{array}$ & $\begin{array}{l}4 \cdot 1(2 \cdot 4) \\
7 \cdot 3(3 \cdot 5)\end{array}$ & $\begin{array}{l}4 \cdot 7(3 \cdot 3) \\
6 \cdot 3(4 \cdot 1)\end{array}$ & $\begin{array}{l}\text { NS } \\
\text { NS }\end{array}$ \\
\hline$H$ pylori infected children (\%) & $33 \cdot 3$ & $66 \cdot 6$ & $34 \cdot 8$ & $34 \cdot 8$ & $21 \cdot 7$ & $<0.05$ \\
\hline
\end{tabular}

$\star$ Age and duration of stay in years mean (SD).
Recent work suggests that childhood could be the main period when $H$ pylori infection is acquired, both in developing countries ${ }^{11}$ and in industrialised countries. ${ }^{12}$

High risk of $H$ pylori infection in cohabiting persons has been confirmed by cases of familial coinfection $^{13}$ with evidence of the same strain among family members. ${ }^{14}$ is In previous studies, we reported the case of children infected by the same strain ${ }^{16}$ and a high prevalence of $H$ pylori infection in mentally retarded children. ${ }^{17}$ On the basis of these findings, however, there is not enough evidence to distinguish between person to person spread or common environmental source of infection, for example, river water ${ }^{18}$ or water source. ${ }^{19}$

To investigate the mode of transmission of $H$ pylori, an epidemiological survey was conducted in a medical centre for mentally retarded children. The aim was to study the prevalence of infection and the distribution of $H$ pylori strains in the institution.

\section{Patients and methods}

\section{SUBJECTS}

After families had been informed and given their approval, all the 117 children living in the institution entered the study. Mean (SD) age was $11 \cdot 2(3 \cdot 6)$ years (range $3 \cdot 5-19$ ), sex ratio $\mathrm{M} / \mathrm{F}$ was $1 \cdot 2$, and no difference in age was found between boys and girls. Eighty three per cent of the patients were white and $17 \%$ were African. No difference was found for age and sex between these two ethnic groups.

Neurological data showed that $29 \%$ could move by themselves, whereas the others could not. Inability to move a finger to the mouth (defined as incoordination) was seen in $40.2 \%$; $57 \cdot 3 \%$ dribbled, and $73 \cdot 5 \%$ were receiving anticonvulsant treatment.

Institutional data were: mean (SD) length of stay in the institution studied was $5 \cdot 1(3 \cdot 1)$ years (range $0.3-10.6$ ), total time spent in an institution was $7 \cdot 6(4)$ years (range: $0 \cdot 5-18 \cdot 3$ ). Children were living in five separate sections with very little contact between sections. Table I shows the differences between the sections: age was higher in sections 1 and 2, lack of mobility and lack of coordination were less common in section 2 , and there was no difference in duration of stay, either in the institution studied or in the total time in an institution.

\section{DIAGNOSIS OF H PYLORI INFECTION}

Serological tests were done for all the children. Presence of antibodies against $H$ pylori was 
Genomic comparison between $\mathrm{H}$ pylori isolates by restriction enzyme analysis. Restriction patterns of antral and fundic isolates from: lanes 1 and 2: child $A$; lanes 3 and $4:$ child $B$; lanes 5 and 6: child $C$; and lanes 7 and 8: child $D$. The same strain is shared by children $A$ and $B$, and another one is shared by children $C$ and $D$.

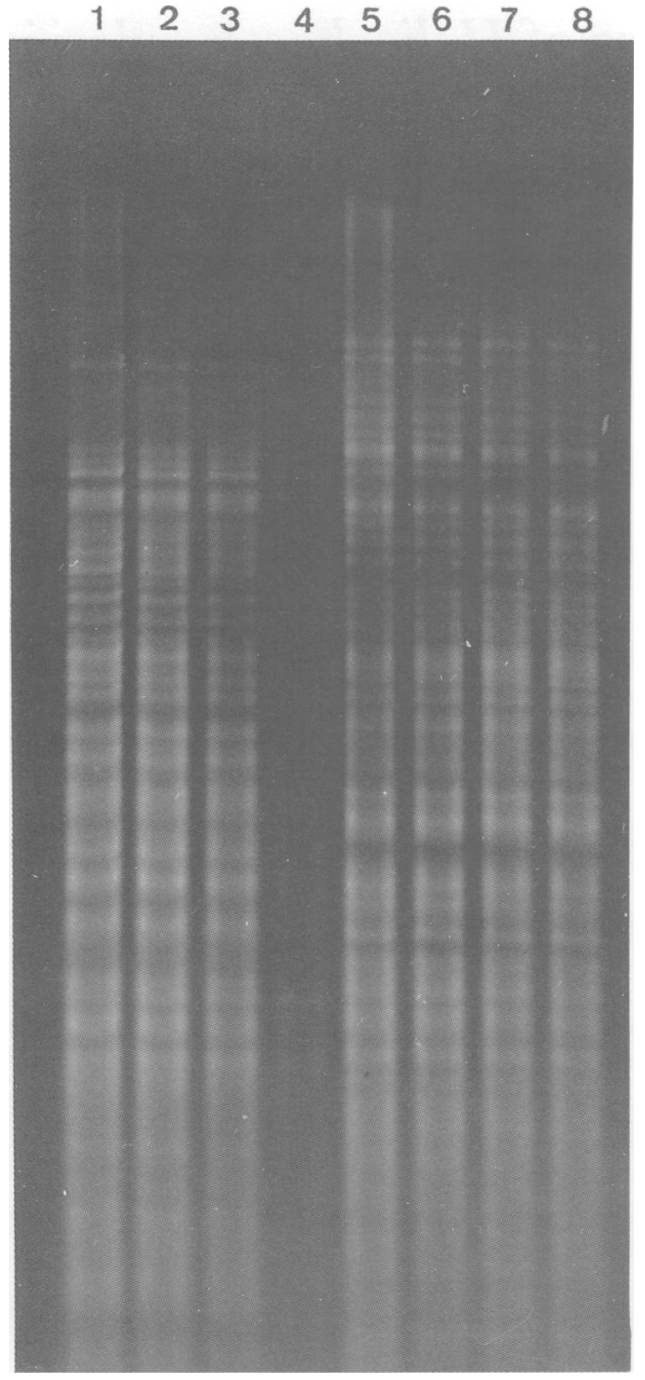

detected by an enzyme linked immunosorbent assay, performed as previously described..$^{20}$ This test was designed to avoid cross reactivity with Campylobacter jejuni, known as a potential infecting organism in mentally retarded people in institutions. $^{3}$

Gastroscopy was performed in each case of positive antibody response to $H$ pylori. For histological investigation, two biopsy specimens were taken from the antrum, and two from the fundus. For bacteriological diagnosis, one biopsy specimen was obtained from the antrum and one from the fundus. Forceps were changed and endoscopes were disinfected before each procedure.

Histopathology - microscopic lesions were ascertained by haematoxylin and eosin staining. Gastritis was defined by the presence of an inflammatory reaction (lymphocytes, plasmocytes, polymorphonuclear cells) or glandular atrophy, or both in at least one biopsy specimen. Presence of spiral bacteria at Giemsa staining in at least one biopsy specimen was also noted.

Microbiology - presence of $H$ pylori in biopsy specimens was studied by (a) direct examination at $\times 100$ with acridine orange staining, (b) urease test, and (c) culture, three to four days in incubation under microaerobic conditions.

Children were considered to be infected by $H$ pylori when both serological tests and culture tests were positive, or when serological tests were positive and at least two of the three following criteria were present: (a) spiral bacteria at Giemsa or acridine orange staining (b) positive urease test, (c) inflammatory reaction of the mucosa.

\section{MOLECULAR EPIDEMIOLOGY}

Genomic finger printing was performed for each $H$ pylori isolate, by restriction enzyme analysis using Hind III and BstE II restriction enzyme, as previously described. ${ }^{21-23}$ When two patterns from different gels seemed to be identical, DNA digests were re-electrophoresed side by side to exclude between gel reproductibility errors. After comparison, the paired patterns were considered as (a) positively identical, coming from the same $H$ pylori strain, when no significant discrepancies were noted (undistinguishable from the background noise); (b) positively different, coming from two $H$ pylori strains, when the two patterns showed no similarities; and (c) questionable, when no epidemiological conclusion could be drawn.

\section{STATISTICAL ANALYSIS}

Analysis was done by comparing percentages $\left(\chi^{2}\right)$ or mean (analysis of variance) between the five sections, and by comparing percentages $\left(\chi^{2}\right)$ or mean ( $t$ test) between infected and uninfected children. Multivariate unconditional logistic regression analysis (SAS software) was done on significant factors to adjust for confounding variables.

\section{Results}

On the basis of serological, histological, and microbiological criteria, 45 children were $H$ pylori infected. The prevalence of infection was $38 \%(45 / 117)$ with significant differences $(\mathrm{p}<0.05)$ between the sections, ranging from $21 \cdot 7 \%(5 / 23)$ to $66 \cdot 7 \%$ (16/24) (Table I). Comparison between $H$ pylori infected and uninfected children gave no differences in the father's occupation, family size, ethnic origin, evidence of dribbling, and need for anti-convulsant treatment. After adjustment for other factors, age, sex, mobility, and incoordination were also similar (Table II). From the institutional point of view, the stay in the institution studied was not significantly longer in infected children, but living in section two was a significant factor for infection $(p=0.02)$, and the total length of stay in institutions was significantly longer (about three years longer) in infected children $(p=0.003)$. Among children who had lived in an institution since their birth, $13 / 17(76 \%)$ were $H$ pylori infected ( $v$ 32/100 among others).

Although serological tests were positive, with spiral shaped bacteria visible at microscopic examination and histological features of infection, culture of $H$ pylori failed in 11 cases. Genomic finger printing was performed on isolates from the 34 remaining cases. Comparison of restriction patterns showed 22 different strains and one epidemiologically questionable pattern. Five strains (S1 to S5) were common to 
TABLE II Characteristics of $\mathrm{H}$ pylori infected or uninfected children and logistic regression analysis

\begin{tabular}{|c|c|c|c|c|c|c|}
\hline & $\begin{array}{l}H p \\
\text { infected } \\
(n=45)\end{array}$ & $\begin{array}{l}H P \\
\text { uninfected } \\
(n=72)\end{array}$ & $\begin{array}{l}\text { Regression } \\
\text { coefficient }\end{array}$ & $S D$ & $\chi^{2}$ & p Value \\
\hline \multicolumn{7}{|l|}{ Demographic data: } \\
\hline $\mathrm{Age}^{\star}$ & $12 \cdot 7(3 \cdot 6)$ & $10 \cdot 3(3 \cdot 2)$ & -0.089 & $0 \cdot 123$ & 0.53 & 0.464 \\
\hline Male (\%) & $66 \cdot 7$ & $45 \cdot 8$ & -0.912 & 0.498 & $3 \cdot 35$ & 0.067 \\
\hline \multicolumn{7}{|l|}{ Neurological state: } \\
\hline Mobile (\%) & $40 \cdot 0$ & $22 \cdot 2$ & $0 \cdot 342$ & 0.615 & $0 \cdot 31$ & 0.578 \\
\hline Coordination (\%) & $73 \cdot 3$ & $51 \cdot 4$ & -0.453 & 0.555 & 0.67 & 0.414 \\
\hline \multicolumn{7}{|l|}{ Institutionalisation: } \\
\hline Living in section $2(\%)$ & $40 \cdot 0$ & $8 \cdot 3$ & $-1 \cdot 989$ & $0 \cdot 857$ & $5 \cdot 38$ & 0.020 \\
\hline $\begin{array}{l}\text { Duration of stay }{ }^{\star} \text { in the institution } \\
\text { studied }\end{array}$ & $5 \cdot 9(3 \cdot 3)$ & $4 \cdot 7(2 \cdot 9)$ & $0 \cdot 210$ & $0 \cdot 135$ & $2 \cdot 41$ & $0 \cdot 120$ \\
\hline Total duration stay ${ }^{\star}$ in institutions & $9 \cdot 6(4 \cdot 1)$ & $6 \cdot 4(3 \cdot 4)$ & -0.337 & 0.115 & 8.63 & 0.003 \\
\hline
\end{tabular}

$\star$ Age and duration of stay in years mean (SD).

more than one child. Strain S1 was common to seven children, five of whom lived in the same section. Strain S2 was common to three children, two of whom lived in the same section, and strains S3, S4, and S5 were common to three groups of two children, each group living in the same section for each group. Strains S6 to S22 were isolated from only one child. Table III shows the distribution of strains throughout the different sections of the institution. Age of entering the section was 3 to 5 years for children infected by the strain $S 1,6$ to $7 \cdot 4$ years for $S 2,5 \cdot 5$ to 10 years for $S 3,6$ to 12 years for $S 4,4$ to $4 \cdot 5$ years for S5. No common factors were found among children infected by the same strain with regard to feeding and care. In some cases, coinfected children shared a room and sanitation, but for those who were sleeping in the same bedroom, their beds were no adjoining.

\section{Discussion}

Compared with the $10 \%$ prevalence reported for French children in general in the same age group $^{1}$ and to prevalences usually reported in children in seven developed countries (less than $20 \%),{ }^{2}$ the prevalence of $H$ pylori infection seen in these mentally retarded cohabiting children was high (up to $67 \%$ of children in section 2). The two other main findings of this study are the difference of prevalence between sections and the high number of different bacterial strains isolated from the institution.

The high prevalence confirms the high risk of $H$ pylori infection for people living in institutions. ${ }^{3-5}$ The main risk factor for these children was living together rather than their neurological state. Age, mobility, and coordination were significantly increased in section 2 but seemed to be confounding variables. After adjustment,

TABLE III Distribution of the 22 different $\mathrm{H}$ pylori strains throughout the sections of the institution

\begin{tabular}{|c|c|c|c|c|c|c|}
\hline & & \multicolumn{5}{|c|}{ Section } \\
\hline & & 1 & 2 & 3 & 4 & 5 \\
\hline \multicolumn{2}{|c|}{$\begin{array}{l}\text { No of isolates } \\
\text { Total number of strains } \\
\text { Strains shared with other sections }\end{array}$} & $\begin{array}{l}4 \\
3 \\
-\end{array}$ & $\begin{array}{r}12 \\
9 \\
1\end{array}$ & $\begin{array}{l}8 \\
4 \\
2\end{array}$ & $\begin{array}{l}7 \\
6 \\
1\end{array}$ & $\begin{array}{l}3 \\
3 \\
-\end{array}$ \\
\hline $\left.\begin{array}{c}\text { No of strains } \\
\text { shared by }\end{array}\right\}$ & $\begin{array}{l}5 \text { children } \\
2 \text { children } \\
1 \text { child }\end{array}$ & $\begin{array}{l}1 \\
2\end{array}$ & $\begin{array}{l}3 \dagger \\
6\end{array}$ & $3 \ddagger$ & $\frac{1 \neq}{5}$ & 3 \\
\hline
\end{tabular}

*Total greater than 22 , since 2 strains were common to several sections; tstrain $S 1$ found in section 3 ( 5 cases) and 2 ( 2 cases); łstrain S2 found in section 4 ( 2 cases) and 3 ( 1 case). infection was not related to deglutition difficulties (dribbling), or to the need for anticonvulsant treatment, or to lack of mobility and coordination. Infection was related to the total duration of stay in institutions but not to age. Moreover, the lack of difference of $H$ pylori infection prevalence between white children and African children is unusual and suggests the predominant role of living conditions, which had been the same for these children for years.

Differences of prevalence between sections show that common physical environment (such as water, food, hygiene conditions, care, and medical staff) can be excluded as a causative agent. Sanitary conditions, in particular, were similar to those usually found in a conventional Western hospital and were identical in all the sections. Moreover, infection was not related to the duration of stay in the institution studied. Molecular typing shows an unequal distribution of the strains throughout the sections (only $2 / 22$ strains were common to several sections), which is not consistent with the hypothesis of a common environmental source of $H$ pylori in the institution. If physical environment is really implied, a still unknown factor specifically only found in section 2 needs to be discovered.

Actually, the most variable factor from one section to another was the human environment. As medical and paramedical staff were the same, the presence of other children living in the same section was the main factor. Because of the high stability of the DNA digest patterns of $H$ pylori, it has been stated that restriction endonucleases analysis was a sensitive and useful method for identifing and comparing isolates. ${ }^{23}$ Comparison of patterns confirms the possibility of cohabiting persons being infected by the same strain. If physical environment can be excluded, these cases of coinfection suggest that interhuman transmission may have occurred in the institution; particularly in section 3 , the five coinfected children entered the section at the age of 3 to 5 years and had been living together for three to seven years. The high number of different strains, however, which were not shared by several children (17/22) suggest that transmission, if any, was not common in this institution. Multiple sources of infection (several strains in each section) cannot be related only to the human environment of the section. It can be assumed that some infections had been acquired before entering the institution, possibly in previous institutions. This is consistent with the relation seen between infection and total duration of stay in institutions.

Living in section 2 remained an important risk factor of infection. In this section, children may have been exposed to a specific and varied source of $H$ pylori, or they may have had different living conditions in their past. No clear explanation, however, can be found in this study to account for the high prevalence in this group.

This study confirms that living in institutions entails a high risk of $H$ pylori infection for children but no obvious source of spread can be found in the physical environment. In humans, most studies looking for $H$ pylor in dental plaque and saliva have been negative, ${ }^{24}$ and found that saliva is probably not a reservoir. The occasional 
presence of regurgitated gastric juice in the mouth, however, could contaminate the secretions of the mouth. Recently $H$ pylori has been seen in some saliva samples by an immunofluorescence technique using monoclonal antibodies, ${ }^{25}$ and specific DNA has been found, using the polymerase chain reaction method. ${ }^{26}$ The similarity in dribbling between infected and uninfected children seen in this study cannot rule out the intermittent presence of the bacteria in saliva, which could therefore lead to the spread of $H$ pylori. Many mentally retarded children living in institutions dribble. They also share objects, such as toys, which are easily put in the mouth and therefore a possible way for contaminating saliva.

This statistical and epidemiological survey of a $H$ pylori infection cluster in 45 among 117 cohabiting children has shown that $H$ pylori infection can be highly prevalent in Western countries, with good hygiene conditions, at low ages, whatever the ethic origin. $H$ pylori infection was not related to the neurological state of children or to environmental sources found specifically in the institution studied but to the total duration of stay in institutions and contact with other high risk children. Because coinfected children have been sharing toys as well as sanitary arrangements, however, whether the transmission is oral or faecal remains questionable.

This work was supported by grant 91310098 from DRED and Conseil Régional Nord-Pas-de Calais, France. Thanks to CERIM, Faculté de Médecine, Lille, for statistical assistance.

1 Megraud F, Brassens-Rabbe MP, Denis F, Belbouri A, Hoa DQ. Seroepidemiology of Campylobacter pylori infection in various population. F Clin Microbiol 1989; 27: 1870-3.

2 Taylor DN, Blaser MJ. The epidemiology of Helicobacter pylori infection. Epidemiol Rev 1991; 13: 42-59.

3 Berkowicz J, Lee A. Person-to-person transmission of Campylobacter plyori. Lancet 1987; i: 680-1.

4 Reiff A, Jacobs E, Kist M. Seroepidemiological study of the immune response to Campylobacter pylori in potential risk groups. Eur f Clin Microbiol Infect Dis 1989; 8: 592-6.

5 Lambert JR, Lin SK, Nicholson L, Shembri M, Sharma V, Kaldor J, et al. Seroepidemiological study of Helicobacter pylori antibodies in institutionalized adults [Abstract]. Rev Esp Enferm Dig 1990; 78: 41-2.

6 Hammermeister I, Janus G, Schamarovski F, Rudolf M, Jacobs E, Kist $M$. Elevated risk of Helicobacter pylor infection in submarine crews. Eur F Clin Microbiol Infect Dis 1992; 11: 9-14.
7 Gottrand F, Turck D, Vincent $P$. Helicobacter pylori infection in early infancy [Letter]. Lancet 1992; 340: 495.

8 Thomas JE, Whatmore AM, Barer MR, Eastham EDJ, Kehoe MA. Serodiagnosis of Helicobacter pylori infection in childhood. F Clin Microbiol 1990; 28: 2641-6.

9 Fiedorek SC, Malaty HM, Evans DL, Pumphrey CL, Casteel $\mathrm{HB}$, Evans DJ, et al. Factors influencing the epidemiology of Helicobacter pylori infection in children. Pediatrics 1991; 88: $578-82$.

10 Perez-Perez GI, Taylor DN, Bodhidatta L, Wongsrichanalai J, Baze WB, Dumm BE, et al. Seroprevalence of Helicobacter pylori infection in Thailand. $\mathcal{F}$ Infect Dis 1990; 161: bacter pylori

11 Mitchell MH, Li YY, Hu PJ, Liu Q, Chen M, Du GG, et al. Epidemiolology of Helicobacter pylori in southern of China: identification of early childhood as the critical period of acquisition. F Infect Dis 1992; 166: 149-53.

12 Mendall MA, Goggin PM, Molineaux N, Levy J, Toosy T, Strachan D, et al. Childhood living conditions and Helicobacter pylori seropositivity in adult life. Lancet 1992; 339 . $896-7$.

13 Drumm B, Perez-Perez GI, Blaser MJ, Sherman PM. Intrafamilial clustering of Helicobacter pylori infection. $N E n g$ f Med 1990; 322: 359-63.

14 Raws EAJ, Langenberg W, Houthoff $\mathrm{HJ}$, Zanen HG, Tytgat GNJ. Familial clustering of peptic ulcer disease colonized with C pylori of the same DNA composition. Gastroenterology 1989; 96: A409.

15 Tee W, Lambert J, Smallwood E, Schembri M, Ross BC Dwyer B. Ribotyping of Helicobacter pylori from clinical specimens. F Clin Microbiol 1992; 30: 1562-7.

16 Vincent $P$, Gottrand F, Pernes P, Husson MO, Béji A, Leclerc $\mathrm{H}$, et al. Helicobacter pylori infection in cohabiting children. [Letter]. Lancet 1991; 337: 848.

17 Gottrand F, Francillette K, Turck D, Vincent P, Lecomte $M$, Farriaux JP. Helicobacter pylori associated gastritis in children. In: Pajeres JM, Lopez-Brea M, Moreno R, eds. Helicobacter pylori and gastroduodenal pathology. Berlin: Springer-Verlag, 1992: 275-7.

18 Shahamat M, Vives-Rego J, Paszko-Kolva C, Pearson AD, Colwell RR. Survival of Campylobacter pylori in river water: ${ }^{3} \mathbf{H}$-thymidine uptake and viability under stimulated environmental conditions [Abstract]. Klin Wochenschr 1989 67: 63 .

19 Klein PD, Graham DY, Gaillour A, Opekun AR, O’Brian Smith $\mathrm{E}$. Water source as risk factor for $\mathrm{H}$ pylori infection in peruvian children. Lancet 1991; 337: 1503-6.

20 Husson MO, Vincent $P$, Grabiaud MH, Furon D, Leclerc $H$ Anti-Helicobacter pylori IgG levels in abattoir workers. Gastroenterol Clin Biol 1991; 15: 723-6.

21 Majewski SIH, Goodwin CS. Restriction endonuclease analysis of the genome of $\mathrm{C}$ pylori with a rapid extraction method: sis of the genome of pylori with a rapid extraction method: 1988; 157: 465-71.

22 Leclerc H, Beji A, Vincent P. Marqueurs moléculaires et identification des souches de Campylobacter pylori. Gastroenterol Clin Biol 1989; 13: 44-8B

23 Langenberg W, Raws EAJ, Widjojokusumo A, Tytgat GNJ Zanen HC. Identification of Campylobacter pylori insolates by restriction endonucleases DNA analysis. F Clin Microbio 1986; $24:$ :14-7.

24 Krajden S, Fuksa M, Anderson J, Kempston J, Boccia A, Petrea C, et al. Examination of human stomach biopsies, saliva and dental plaque for Campylobacter pylori. $\mathcal{f} \mathrm{Clin}$ Microbiol 1989; 27: 1397-8.

25 Husson MO, Gottrand F, Turck D, Leclerc $\mathrm{H}$. Detection of Helicobacter pylori in saliva by use of a monoclonal Helicobacter pylori in saliva by use of a

26 Birac C, Tall F, Abenque M, Labigne A, Mégraud F. PCR to detect Helicobacter pylori in the mouth [Abstract]. Ir $\mathcal{F}$ Med Sci 1992; 161 (suppl X): 28. 